\title{
Promoter-Specific Hypomethylation Correlates with IL-1 $\beta$ Overexpression in Tuberous Sclerosis Complex (TSC)
}

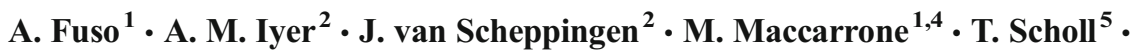 \\ J. A. Hainfellner ${ }^{6}$ - M. Feucht ${ }^{5}$ - F. E. Jansen ${ }^{7}$ - W. G. Spliet ${ }^{8}$ • P. Krsek ${ }^{9}$ • J. Zamecnik ${ }^{10}$. \\ A. Mühlebner ${ }^{2,5} \cdot$ E. Aronica ${ }^{2,3,11}$
}

Received: 18 March 2016 / Accepted: 24 March 2016/Published online: 28 April 2016

(C) The Author(s) 2016. This article is published with open access at Springerlink.com

\begin{abstract}
In tuberous sclerosis complex (TSC), overexpression of numerous genes associated with inflammation has been observed. Among different proinflammatory cytokines, interleukin-1 $\beta$ (IL-1 $\beta$ ) has been shown to be significantly involved in epileptogenesis and maintenance of seizures. Recent evidence indicates that IL-1 $\beta$ gene expression can be regulated by DNA methylation of its promoter. In the present study, we hypothesized that hypomethylation in the promoter region of the IL-1 $\beta$ gene may underlie its overexpression observed in TSC brain tissue. Bisulfite sequencing was used to study the methylation status of the promoter region of the IL-1 $\beta$ gene in TSC and control samples. We identified hypomethylation in the promoter region of the IL- $1 \beta$ gene in TSC samples. IL-1 $\beta$ is overexpressed in tubers, and gene expression is correlated with promoter hypomethylation at $\mathrm{CpG}$ and non-CpG sites. Our results provide the first evidence of epigenetic modulation of the IL- $1 \beta$ signaling in TSC. Thus, strategies that target epigenetic alterations could offer new
\end{abstract}

A. Fuso and A.M. Iyer contributed equally to this work

\section{E. Aronica}

e.aronica@amc.uva.nl

1 European Center for Brain Research (CERC)/IRCCS Santa Lucia Foundation, Via del Fosso di Fiorano 64-65, 00143 Rome, Italy

2 Department of (Neuro)Pathology, Academic Medical Center, University of Amsterdam, Meibergdreef 9, 1105

AZ Amsterdam, The Netherlands

3 Swammerdam Institute for Life Sciences, Center for Neuroscience, University of Amsterdam, Amsterdam, The Netherlands

4 Department of Medicine, Campus Bio-Medico University of Rome, Rome, Italy

5 Department of Pediatrics, Medical University Vienna, Vienna, Austria therapeutic avenues to control the persistent activation of interleukin-1 $\beta$-mediated inflammatory signaling in TSC brain.

Keywords Tuberous sclerosis complex · Cortical tuber · Inflammation $\cdot$ Interleukin- $1 \beta \cdot$ Epigenetic regulation

\section{Introduction}

Tuberous sclerosis complex (TSC) is a multisystem genetic disorder that results from a mutation in the TSC1 or TSC2 genes leading to constitutive activation of mammalian target of rapamycin complex 1 (mTORC1) and is therefore highly associated with intractable epilepsy (Curatolo et al. 2015). Cortical tubers are believed to represent the neuropathological substrate in TSC patients. However, a growing body of evidence supports the existence of a more extensive epileptogenic

6 Institute of Neurology, Medical University Vienna, Vienna, Austria

7 Department of Pediatric Neurology, Brain Center Rudolf Magnus, University Medical Center Utrecht, Utrecht, The Netherlands

8 Department of Pathology, University Medical Center Utrecht, Utrecht, The Netherlands

9 Department of Pediatric Neurology, 2nd Faculty of Medicine, Charles University, Motol University Hospital,

Prague, Czech Republic

10 Department of Pathology, 2nd Faculty of Medicine, Charles University, Motol University Hospital, Prague, Czech Republic

11 Stichting Epilepsie Instellingen Nederland (SEIN), Heemstede, The Netherlands 
network in TSC patients (Marcotte et al. 2012; Okanishi et al. 2014). Cortical tubers, but to a certain extent also the perituberal cortex, are characterized by a complex activation of pro-inflammatory signaling pathways, including, in particular, the IL-1 $\beta$ signaling pathway (Boer et al. 2010; Boer et al. 2008). Expression of both IL- $1 \beta$ and its receptor was observed in astrocytes, cells of the microglia/macrophage lineage, dysmorphic neurons, and giant cells displaying mTOR activation (Boer et al. 2008). Evaluation of fetal TSC cases demonstrated an activation of the IL-1 receptor (R)/Toll-like receptor (TLR) pathway also in developing TSC brain lesions (Prabowo et al. 2013), suggesting that the induction of this pathway could be intrinsic to the developmental lesion and linked to the deregulation of the mTOR pathway.

Recent evidence suggests that pro-inflammatory cytokines, including IL-1 $\beta$, can be epigenetically regulated through DNA methylation at their promoters (Aoi et al. 2011; Hashimoto et al. 2013; Kirchner et al. 2014; Tekpli et al. 2013). In particular, a recent study shows that, in mice and humans, hypomethylation of IL- $1 \beta$ at specific $\mathrm{CpG}$ sites is associated with elevated IL-1 $\beta$ transcription. Hence, this epigenetic mechanism may contribute to cognitive deficits in aging and neurodegenerative diseases (Cho et al. 2015). The influence of epigenetic regulation of IL- $1 \beta$ in TSC brain remains as yet unclear. We hypothesized therefore that hypomethylation in the promoter region of the IL-1 $\beta$ gene may underlie its overexpression observed in tubers.

\section{Patients and Methods}

\section{Patient Cohort}

The cases included in this study were obtained from the archives of the departments of neuropathology of the Academic Medical Center (AMC, University of Amsterdam), University Medical Center in Utrecht (UMCU), Motol University Hospital (Prague, Czech Republic), and Medical University Vienna (Vienna, Austria). We evaluated five tubers (three surgical and two autopsy specimens; mean age, 15.8 years; male/ female, 2/3; localization, frontal/temporal/parietal, 3/1/1; TSC1/TSC2, 1/4). Four cases (two autopsy/two surgical; male/female, 1/3; mean age: 18.4 years; TSC1/TSC2:1/3) contained sufficient amount of perituberal tissue, defined by the absence of dysmorphic neurons and giant cells. The ageand localization-matched control group consisted of six autopsy cases (male/female, 2/4; mean age, 13.5 years; frontal/temporal/parietal, 4/1/1). None of these patients had a history of seizures or other neurological diseases.

Tissues were obtained and used in accordance with the Declaration of Helsinki and the AMC Research Code provided by the Medical Ethics Committee. The local ethical committees of all participating centers gave permission to undertake the study.

\section{Tissue Preparation}

Brain tissues from control autopsy patients and TSC patients were snap frozen in liquid nitrogen and stored at $-80^{\circ} \mathrm{C}$ until further use. Formalin-fixed paraffin-embedded tissues were sectioned at $6 \mu \mathrm{m}$, mounted on pre-coated glass slides (Star Frost, Waldemar Knittel GmbH, Braunschweig, Germany). Immunohistochemistry for IL-1 $\beta$ (polyclonal goat antibody; sc-1250, Santa Cruz Bio., CA, USA; 1:70) was carried out on paraffin-embedded tissue as previously described (Boer et al. 2008; Ravizza et al. 2006). Sections were deparaffinated in xylene, rinsed in ethanol $(100,95$, and $70 \%)$, and incubated for $20 \mathrm{~min}$ in $0.3 \%$ hydrogen peroxide diluted in methanol. Antigen retrieval was performed using a pressure cooker in $0.1 \mathrm{M}$ citrate buffer $\mathrm{pH} 6.0$ at $120^{\circ} \mathrm{C}$ for $10 \mathrm{~min}$. Slides were washed with phosphate-buffered saline (PBS; 0.1 M, pH 7.4) and incubated overnight with the primary antibody in PBS at $4{ }^{\circ} \mathrm{C}$. After washing in PBS, sections were incubated with rabbit anti-goat IgG (hum absorb, SBA 6164-01, 1:2000, $15 \mathrm{~min}$ ), subsequently with polymer goat anti-rabbit IgG/ HRP (BrightVision, DPVM-15HRP, undiluted, $30 \mathrm{~min}$ ) and stained using 3,3'-diaminobenzidine tetrahydrochloride as chromogen. Sections were counterstained with hematoxylin, dehydrated in alcohol and xylene, and coverslipped. The specificity of the antibody was tested by pre-incubating the antibody with a 100-fold excess of the antigenic peptides (Santa Cruz Bio. and R\&D Systems). Sections incubated without the primary $\mathrm{Ab}$ or with the primary $\mathrm{Ab}$ and an excess of the antigenic peptide were essentially blank (Ravizza et al. 2006). Paraffin-embedded human specimens of gliomas (Giometto et al. 1996; Sasaki et al. 1998), multiple sclerosis (Huitinga et al. 2000), and viral encephalitis (herpes simplex encephalitis and rabies encephalitis) were used as positive controls for immunocytochemical staining. For doublelabeling studies, sections were incubated with the primary antibodies (anti-IL-1 $\beta$ and anti-GFAP; monoclonal mouse, Sigma, St. Louis, Mo, USA; 1:4000) and were incubated for $2 \mathrm{~h}$ at RT with Alexa Fluor ${ }^{\circledR} 568$-conjugated anti-goat IgG and Alexa Fluor ${ }^{\circledR} 488$ anti-mouse, IgG (1:200, Molecular Probes, The Netherlands). Sections were then analyzed by means of a laser scanning confocal microscope (Leica TCS Sp2, Wetzlar, Germany).

\section{DNA Methylation Analysis by Bisulfite Modification and Genomic Sequencing}

DNA was extracted from frozen tissue material of controls and TSC patients using the QIAamp DNA Mini Kit (Qiagen, Venlo, The Netherlands). DNA methylation analysis was carried out as previously described (Fuso et al. 2015). Briefly, bisulfite analysis 
of $I L-1 \beta$ promoter methylation was performed using the EpiTect Bisulfite kit; PCR products obtained after bisulfite treatment were cloned using the PCR Plus Cloning Kit (both from Qiagen). At least ten clones were analyzed per experimental condition using M13 primers for sequencing performed by Primm (Milan, Italy). The primers used for the amplification of the bisulfite-modified DNA were designed on the GenBank AY137079.1 sequence, considering the 5'-flanking region (Fig. 1a) of the messenger RNA (mRNA) (TSS at the base n. 1306 ). These primers (HSIL1BBISL, 5' AAAGAAGTGAATGAAGAAAAGTATGTG-3'; HSIL 1 BBISR, 5' - A ATACCTRATTTCACAATCA ARTTAAA-3') amplified a 315-bp sequence (916-1230), containing 64 cytosines including two CpG moieties (1006 and 1049). These primers are "methylation insensitive primers" (MIPs) that can detect methylation in both $\mathrm{CpG}$ and in nonCpG moieties (Fuso et al. 2015) and allow assessing methylation status of plus (5'-3') DNA strand.

As negative controls of bisulfite modifications, we used unmethylated purified PCR product of $I L-1 \beta$ promoter obtained from genomic DNA by the same primers used for the amplification of the bisulfite-treated DNA. The same purified PCR product was methylated in vitro with SssI methylase (New England Biolabs, EuroClone, Milan, Italy) and was used as positive controls.

Modified cytosine residues were recognized through comparison with the original DNA sequence, and methylation status of any single cytosine in each sequenced clone was reported as 1/0 value in an Excel spreadsheet (methylated, 1; unmethylated, 0). For each experimental sample, we obtained the methylation percentage of each single cytosine by calculating the number of methylated cytosines divided by the number of clones sequenced per 100 ([no. methylC/no. sequenced clones] $\times 100$; (Fuso et al. 2015)).

\section{RNA Isolation and Real-Time Quantitative PCR Analysis}

For RNA isolation, frozen material was homogenized in Qiazol Lysis Reagent (Qiagen Benelux, Venlo, the Netherlands). Total RNA was isolated using the miRNeasy Mini kit (Qiagen Benelux, Venlo, the Netherlands). The concentration and purity of RNA were determined using a Nanodrop 2000 spectrophotometer (Thermo Scientific, Wilmington, DE, USA). To evaluate the expression of IL- $1 \beta$ mRNA in control and TSC tissues, $5 \mu \mathrm{g}$ of total RNA was reverse-transcribed into complementary (cDNA) using oligo dT primers. Specific primers were designed using the Universal ProbeLibrary Assay Design Center of Roche (https://www.roche-applied-science.com) on the basis of the reported mRNA sequences. The following primers were used: IL-1 $\beta$ (forward: gcatccagctacgaatctcc reverse: gaaccagcatcttcctcagc, product size $99 \mathrm{nt}$ ); elongation factor 1-alpha (EF1 $\alpha$; forward: atccacctttgggtcgcttt; reverse: ccgcaactgtctgtctcatatcac, product size $51 \mathrm{nt}$ ). Qualitative realtime PCR (qRT-PCR) and quantification was performed as previously described (Prabowo et al. 2015). Briefly, for $1 \mu \mathrm{l}$ cDNA, a master mix was prepared containing $2 \mathrm{X}$ SensiFAST ${ }^{\mathrm{TM}}$ SYBR No-ROX (Bioline, Taunton, MA, USA) forward and reverse primers in a total volume of $5 \mu$ l. The samples were

A

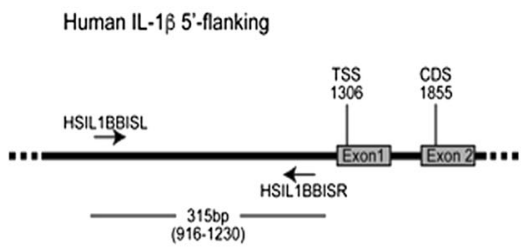

B

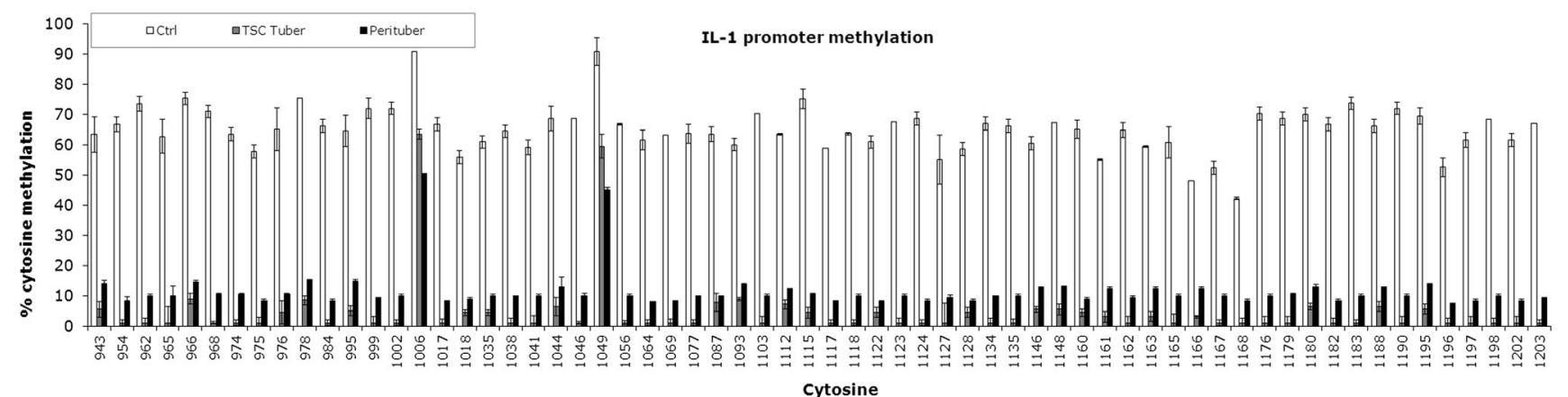

Fig. 1 Methylation pattern of IL- $1 \beta$ promoter in controls and TSC brain tissue. a Schematic representation of the $5^{\prime}$-flanking region on the $I L-1 \beta$ gene, reporting the position of primers used in the bisulfite analysis and the position of the transcription start site (TSS) and the start site of the coding sequence $(C D S)$. b $\mathrm{CpG}$ and non-CpG site-specific methylation pattern expressed as percent methylation for each cytosine in the investigated region of the human $I L-1 \beta$ promoter. Cytosine position in the reference sequence is indicated below the $x$-axis. White columns represent control samples, gray columns represent tuber samples, and black columns represent perituberal tissue samples 
run in triplicate in a 384-well plate in the LightCycler ${ }^{\circledR} 480$ Real-Time PCR System (Roche Applied Sciences) under the following conditions: a 2 -min denaturing step at $95{ }^{\circ} \mathrm{C}$ followed by a total of 45 amplification cycles consisting of $5 \mathrm{~s}$ of denaturing at $95^{\circ} \mathrm{C}, 10 \mathrm{~s}$ of annealing at $65^{\circ} \mathrm{C}$, and $15 \mathrm{~s}$ of extension at $72{ }^{\circ} \mathrm{C}$. Fluorescent product was measured by a single acquisition mode at $72{ }^{\circ} \mathrm{C}$ after each cycle. Quantification of data was performed using the computer program LinRegPCR in which linear regression on the Log (fluorescence) per cycle number data is applied to determine the amplification efficiency per sample as described (Ramakers et al. 2003; Ruijter et al. 2009). The starting concentration of each specific product was divided by the starting concentration of reference gene (elongation factor 1-alpha (EF1)), and this ratio was compared between groups. The results were expressed as fold change with respect to control values.

\section{Statistical Analysis}

Statistical analyses were performed using the GraphPad Prism ${ }^{\circledR}$ software (GraphPad software Inc., La Jolla, CA, USA). The non-parametric Kruskal-Wallis test followed by pairwise comparison was used to analyze DNA methylation differences and the expression of IL- $1 \beta$ between multiple groups. The correlation between DNA methylation and IL$1 \beta$ gene expression was analyzed by Spearman's rank correlation analysis.

\section{Results}

All the five tubers displayed similar histopathological features with astrogliosis, loss of lamination, giant cells, and dysmorphic neurons.

Significant overall hypomethylation of the $I L-1 \beta$ promoter was observed between the groups [Kruskal-Wallis
$\mathrm{H}[2]=10.485, p<0.01]$. However, pairwise comparison revealed significant differences in methylation read counts in tubers and control tissue $(p<0.01)$ while a trend towards hypomethylation was seen in perituberal tissue compared to controls. The hypomethylation was particularly evident for non-CpG moieties $(p<0.001$, tubers and perituberal tissues vs. control tissues) although the two $\mathrm{CpG}$ moieties (cytosines 1006 and 1049, $p<0.01$ ) also showed significant hypomethylation compared to control tissues (Fig. 1b).

Increased expression of IL- $1 \beta$ mRNA was observed in tubers $(p<0.01)$, whereas a trend to increased expression was observed in the perituberal cortex as compared to controls (Fig. 2b) by qRT-PCR. A significant inverse correlation was observed between the extent of DNA methylation and gene expression (Fig. 2c; $r=-0.7929, p<0.001$ ) by Spearman's rank correlation analysis.

In agreement with previous reports (Boer et al. 2008; Ravizza et al. 2006), increased IL-1 $\beta$ expression was detected in TSC tubers as compared to control tissue; expression of IL$1 \beta$ was observed in glial and neuronal cells, as well as in giant cells within the tuber (Fig. 3a, b).

\section{Discussion}

Previous studies have identified altered gene expression in brain lesions typical for TSC, in particular, an enhanced expression of numerous genes associated with the immune and inflammatory response (for review, see Aronica and Crino (2014)). However, these studies have not provided insights into the underlying mechanisms of transcriptional dysregulation, such as aberrant epigenetic control through DNA hypoand/or hypermethylation. In this study, we focused on IL-1 $\beta$, a pro-inflammatory cytokine, strongly deregulated in TSC human brain and known to play a key pathogenic role in human epilepsy (Vezzani et al. 2013). Herein, we described
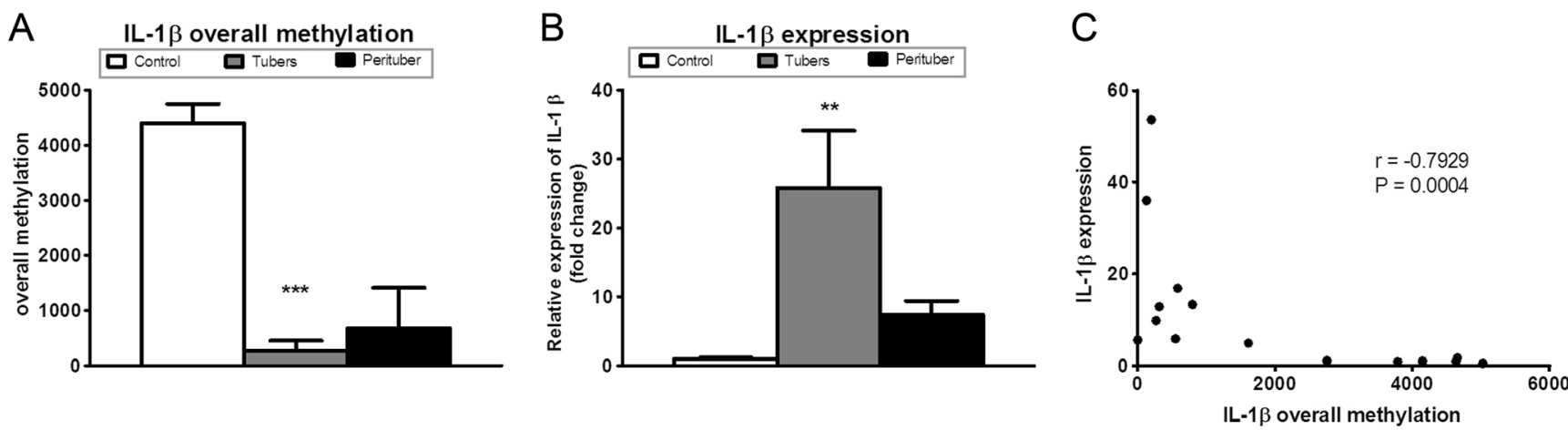

Fig. 2 IL-1 $\beta$ promoter hypomethylation correlates with gene expression. a Overall sites of methylation $(\mathrm{CpG}$ and non- $\mathrm{CpG})$ in the investigated region of the human $I L-1 \beta$ promoter. b Quantitative real-time PCR of IL$1 \beta$ mRNA expression in TSC and control samples, expressed as fold change with respect to controls; white columns represent control

samples, gray columns represent tuber samples, and black columns represent perituberal tissue samples. $\mathbf{c}$ Correlation between IL-1 $\beta$ DNA methylation ( $x$-axis) and gene expression ( $y$-axis). $r=$ Spearman's rank correlation coefficient, $* * p<0.01, * * * p<0.001$ 


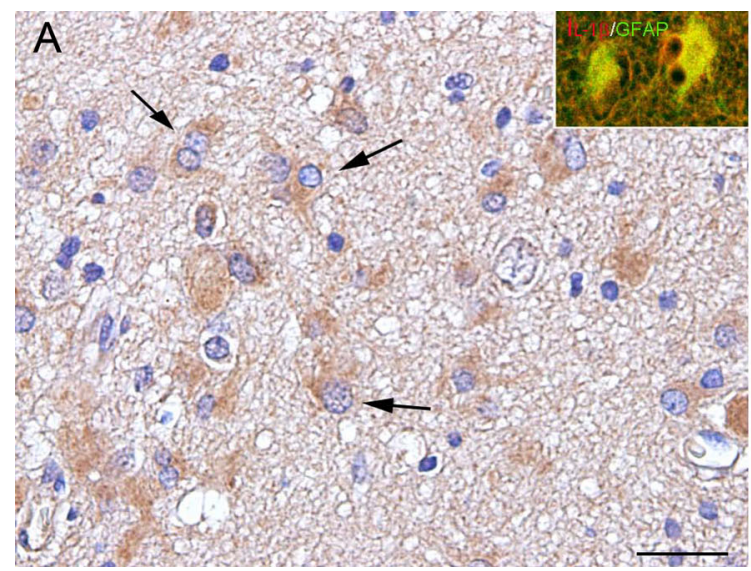

Fig. 3 Expression of IL-1 $\beta$ immunoreactivity (IR) in cortical tubers. a, b IL-1 $\beta$ IR is observed in reactive astrocytes (arrows) and in giant cells (asterisks) in TSC brain (cortical tuber); inset in (a) is a merged image,

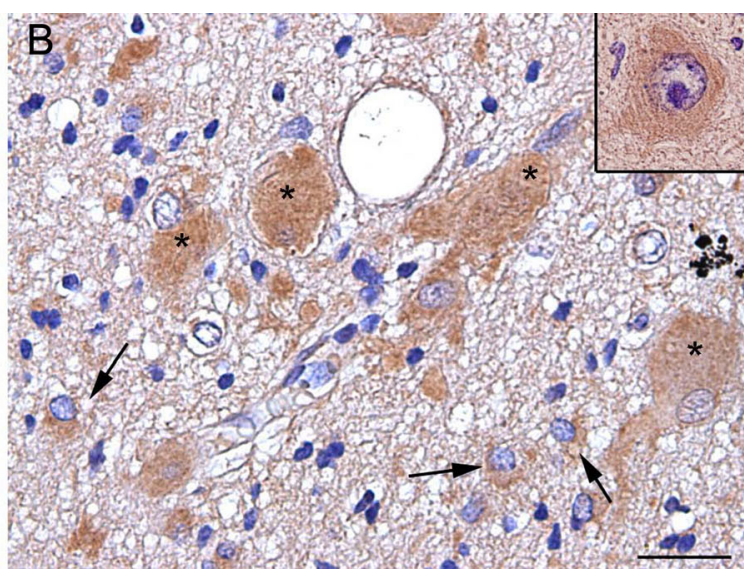

showing expression of IL- $1 \beta$ in GFAP-positive cells; inset in (b) shows a positive dysmorphic neuron. Scale bars $40 \mu \mathrm{m}$

regulation of cytokines, including IL-1 $\beta$ (Auron and Webb 1994; Fenton 1992; Simi et al. 2007). IL-1 $\beta$ expression is regulated by components of the complement cascade, several cytokines (including and IL-1 $\beta$ itself; (Fenton 1992 Lucas, $2006 \# 33,912)$ ), and damage-associated molecular pattern molecules, which include high-mobility group box 1 (HMGB1; (Pedrazzi et al. 2007)). Interestingly, cortical tubers are characterized by prominent activation of proinflammatory signaling pathways, including in particular the complement and Toll-like receptor pathways and HMGB1 signaling (Boer et al. 2010; Boer et al. 2008; Zurolo et al. 2011). Attention has been also recently focused on binding proteins and microRNAs, which may directly regulate the stability and/or translation of cytokine mRNAs (Palanisamy et al. 2012) and interact with IL-1 $\beta$ signaling pathway via complex positive and negative feedback loops. (He et al. 2014; O'Neill et al. 2011; Quinn and O’Neill 2011; van Scheppingen et al. 2016). Finally, since patients received several antiepileptic drugs, such as valproic acid, a possible effect of drug treatment on DNA methylation patterns (Ni et al. 2015), as well as on IL-1 $\beta$ expression (Gomez et al. 2014; Verrotti et al. 2001), has to be taken into consideration in the interpretation of the expression data in TSC brain specimens.

In summary, the presented data demonstrated the potential role of gene-specific DNA hypomethylation inducing aberrant transcriptional control that may lead to the increased expression of IL-1 $\beta$ under pathological conditions. Thus, strategies that target epigenetic alterations, combined with conventional therapies, could offer new therapeutic avenues to control the IL-1 $\beta$-mediated signaling and to develop a more personalized treatment in TSC patients.

Acknowledgments This work was supported by the Framework Programme FP7/2007-2013 under the project acronym EPISTOP (grant 
agreement no. 602391; AMI, JvS, TS, MF, FJ, PK, EA) and by the Austrian Science Fund (FWF): project no. J3499 (AM). We confirm that we have read the Journal's position on issues involved in ethical publication and affirm that this report is consistent with those guidelines.

Author Contributions $\mathrm{AF}$ and MM performed DNA methylation studies, JvS and AMI prepared DNA and RNA from TSC brain tissue and carried out qPCR and immunohistochemistry. TS, MF, JAH, FJ, WGS, PK, JZ, and AM contributed to the collection of tissue samples. The overall experimental design was conceived and supervised by EA and $\mathrm{AF}$. AM and AMI helped in preparing the manuscript for submission. All authors read, revised, and approved the final manuscript.

Compliance with Ethical Standards Tissues were obtained and used in accordance with the Declaration of Helsinki and the AMC Research Code provided by the Medical Ethics Committee. The local ethical committees of all participating centers gave permission to undertake the study.

Conflicts of Interest None of the authors have competing interests or other interests that might be perceived to influence the results and/or discussion reported in this article.

Open Access This article is distributed under the terms of the Creative Commons Attribution 4.0 International License (http:// creativecommons.org/licenses/by/4.0/), which permits unrestricted use, distribution, and reproduction in any medium, provided you give appropriate credit to the original author(s) and the source, provide a link to the Creative Commons license, and indicate if changes were made.

\section{References}

Abs E, Goorden SM, Schreiber J, Overwater IE, Hoogeveen-Westerveld M, Bruinsma CF, Aganovic E, Borgesius NZ, Nellist M, Elgersma Y (2013) TORC1-dependent epilepsy caused by acute biallelic Tsc1 deletion in adult mice. Ann Neurol 74:569-579

Aoi Y, Nakahama K, Morita I, Safronova O (2011) The involvement of DNA and histone methylation in the repression of IL-1beta-induced MCP-1 production by hypoxia. Biochem Biophys Res Commun 414:252-258

Aronica E, Crino PB (2014) Epilepsy related to developmental tumors and malformations of cortical development. Neurotherapeutics 11(2):251-268

Auron PE, Webb AC (1994) Interleukin-1: a gene expression system regulated at multiple levels. Eur Cytokine Netw 5:573-592

Boer K, Crino PB, Gorter JA, Nellist M, Jansen FE, Spliet WG, van Rijen PC, Wittink FR, Breit TM, Troost D, et al. (2010) Gene expression analysis of tuberous sclerosis complex cortical tubers reveals increased expression of adhesion and inflammatory factors. Brain Pathol 20:704-719

Boer K, Jansen F, Nellist M, Redeker S, van den Ouweland AM, Spliet WG, van Nieuwenhuizen O, Troost D, Crino PB, Aronica E (2008) Inflammatory processes in cortical tubers and subependymal giant cell tumors of tuberous sclerosis complex. Epilepsy Res 78:7-21

Cho SH, Chen JA, Sayed F, Ward ME, Gao F, Nguyen TA, Krabbe G, Sohn PD, Lo I, Minami S, et al. (2015) SIRT1 deficiency in microglia contributes to cognitive decline in aging and neurodegeneration via epigenetic regulation of IL-1beta. J Neurosci 35:807-818

Curatolo P, Moavero R, de Vries PJ (2015) Neurological and neuropsychiatric aspects of tuberous sclerosis complex. Lancet Neurol 14: 733-745
Fenton MJ (1992) Review: transcriptional and post-transcriptional regulation of interleukin 1 gene expression. Int J Immunopharmacol 14: 401-411

Fuso A, Ferraguti G, Scarpa S, Ferrer I, Lucarelli M (2015) Disclosing bias in bisulfite assay: MethPrimers underestimate high DNA methylation. PLoS One 10:e0118318

Giometto B, Bozza F, Faresin F, Alessio L, Mingrino S, Tavolato B (1996) Immune infiltrates and cytokines in gliomas. Acta Neurochir 138:50-56

Gomez CD, Buijs RM, Sitges M (2014) The anti-seizure drugs vinpocetine and carbamazepine, but not valproic acid, reduce inflammatory IL-1 beta and TNF-alpha expression in rat hippocampus. J Neurochem 130:770-779

Hashimoto K, Otero M, Imagawa K, de Andres MC, Coico JM, Roach HI, Oreffo RO, Marcu KB, Goldring MB (2013) Regulated transcription of human matrix metalloproteinase 13 (MMP13) and interleukin-1beta (IL1B) genes in chondrocytes depends on methylation of specific proximal promoter CpG sites. J Biol Chem 288: 10061-10072

He X, Jing Z, Cheng G (2014) MicroRNAs: new regulators of Toll-like receptor signalling pathways. Biomed Res Int 2014:945169

Huitinga I, van der Cammen M, Salm L, Erkut Z, van Dam A, Tilders F, Swaab D (2000) IL-1beta immunoreactive neurons in the human hypothalamus: reduced numbers in multiple sclerosis. J Neuroimmunol 107:8-20

Kirchner H, Nylen C, Laber S, Barres R, Yan J, Krook A, Zierath JR, Naslund E (2014) Altered promoter methylation of PDK4, IL1 B, IL6, and TNF after Roux-en Y gastric bypass. Surg Obes Relat Dis 10:671-678

Lozovaya N, Gataullina S, Tsintsadze T, Tsintsadze V, Pallesi-Pocachard E, Minlebaev M, Goriounova NA, Buhler E, Watrin F, Shityakov S, et al. (2014) Selective suppression of excessive GluN2C expression rescues early epilepsy in a tuberous sclerosis murine model. Nat Commun 5:4563

Marcotte L, Aronica E, Baybis M, Crino PB (2012) Cytoarchitectural alterations are widespread in cerebral cortex in tuberous sclerosis complex. Acta Neuropathol 123:685-693

Ni G, Qin J, Li H, Chen Z, Zhou Y, Fang Z, Chen Y, Zhou J, Huang M, Zhou L (2015) Effects of antiepileptic drug monotherapy on onecarbon metabolism and DNA methylation in patients with epilepsy. PLoS One 10:e 0125656

O'Neill LA, Sheedy FJ, McCoy CE (2011) MicroRNAs: the fine-tuners of Toll-like receptor signalling. Nat Rev Immunol 11:163-175

Okanishi T, Akiyama T, Tanaka S, Mayo E, Mitsutake A, Boelman C, Go C, Snead OC 3rd, Drake J, Rutka J, et al. (2014) Interictal high frequency oscillations correlating with seizure outcome in patients with widespread epileptic networks in tuberous sclerosis complex. Epilepsia 55:1602-1610

Palanisamy V, Jakymiw A, Van Tubergen EA, D'Silva NJ, Kirkwood KL (2012) Control of cytokine mRNA expression by RNA-binding proteins and microRNAs. J Dent Res 91:651-658

Pedrazzi M, Patrone M, Passalacqua M, Ranzato E, Colamassaro D, Sparatore B, Pontremoli S, Melloni E (2007) Selective proinflammatory activation of astrocytes by high-mobility group box 1 protein signaling. J Immunol 179:8525-8532

Prabowo AS, Anink JJ, Lammens M, Nellist M, van den Ouweland AM, Adle-Biassette H, Sarnat HB, Flores-Sarnat L, Crino PB, Aronica E (2013) Fetal brain lesions in tuberous sclerosis complex: TORC1 activation and inflammation. Brain Pathol 23:45-59

Prabowo AS, van Scheppingen J, Iyer AM, Anink JJ, Spliet WG, van Rijen PC, Schouten-van Meeteren AY, Aronica E (2015) Differential expression and clinical significance of three inflammation-related microRNAs in gangliogliomas. J Neuroinflammation 12:97

Quinn SR, O'Neill LA (2011) A trio of microRNAs that control Toll-like receptor signalling. Int Immunol 23:421-425 
Ramakers C, Ruijter JM, Deprez RH, Moorman AF (2003) Assumptionfree analysis of quantitative real-time polymerase chain reaction (PCR) data. Neurosci Lett 339:62-66

Ravizza T, Boer K, Redeker S, Spliet WG, van Rijen PC, Troost D, Vezzani A, Aronica E (2006) The IL-1beta system in epilepsyassociated malformations of cortical development. Neurobiol Dis 24:128-143

Ruijter JM, Ramakers C, Hoogaars WM, Karlen Y, Bakker O, van den Hoff MJ, Moorman AF (2009) Amplification efficiency: linking baseline and bias in the analysis of quantitative PCR data. Nucleic Acids Res 37:e45

Sasaki A, Tamura M, Hasegawa M, Ishiuchi S, Hirato J, Nakazato Y (1998) Expression of interleukin-1beta mRNA and protein in human gliomas assessed by RT-PCR and immunohistochemistry. J Neuropathol Exp Neurol 57:653-663

van Scheppingen J, Iyer AM, Prabowo A, Mühlebner A, Anink J, Scholl T, Feucht M, Jansen FE, Spliet M, Krsek P et al. 2016. Expression of microRNAs miR21, miR146a and miR155 in tuberous sclerosis complex cortical tubers and their regulation in human astrocytes and SEGA-derived cell cultures. Glia in press.
Simi A, Lerouet D, Pinteaux E, Brough D (2007) Mechanisms of regulation for interleukin-1beta in neurodegenerative disease. Neuropharmacology 52:1563-1569

Tekpli X, Landvik NE, Anmarkud KH, Skaug V, Haugen A, Zienolddiny S (2013) DNA methylation at promoter regions of interleukin 1B, interleukin 6, and interleukin 8 in non-small cell lung cancer. Cancer Immunol Immunother 62:337-345

Verrotti A, Basciani F, Trotta D, Greco R, Morgese G, Chiarelli F (2001) Effect of anticonvulsant drugs on interleukins-1, -2 and -6 and monocyte chemoattractant protein-1. Clin Exp Med 1:133-136

Vezzani A, Aronica E, Mazarati A, Pittman QJ (2013) Epilepsy and brain inflammation. Exp Neurol 244:11-21

Xie J, Zhang X, Zhang L (2013) Negative regulation of inflammation by SIRT1. Pharmacol Res 67:60-67

Zhang B, Zou J, Rensing NR, Yang M, Wong M (2015) Inflammatory mechanisms contribute to the neurological manifestations of tuberous sclerosis complex. Neurobiol Dis 80:70-79

Zurolo E, Iyer A, Maroso M, Carbonell C, Anink JJ, Ravizza T, Fluiter K, Spliet WG, van Rijen PC, Vezzani A, et al. (2011) Activation of tolllike receptor, RAGE and HMGB1 signalling in malformations of cortical development. Brain 134:1015-1032 